\title{
Area-based lidar-assisted estimation of forest standing volume
}

\author{
Piermaria Corona and Lorenzo Fattorini
}

\begin{abstract}
Airborne laser scanning (lidar) technology is increasingly being applied in forest ecosystem surveys. This research note proposes a design-based approach for the lidar-assisted estimation of forest standing volume when ground surveys are performed by means of fixed-area plots. The lidar measurement of the height of the upper canopy (digital crown model) is performed for the whole study area, and the resulting pixel heights are adopted as auxiliary information to couple with the standing volume acquired on the ground by means of sample plots. The ratio estimator for the total volume of the forest is derived in a complete design-based framework together with an unbiased estimator of its sampling variance and the corresponding confidence interval. The proposed procedure has been tested in Bosco della Fontana, a lowland forest in Northern Italy, obtaining a 95\% confidence interval for the total volume, which is approximately $2 / 3$ smaller than that obtained by solely using information arising from field plots.
\end{abstract}

Résumé : La technologie du laser à balayage aéroporté (lidar) est de plus en plus appliquée pour l'inventaire des écosystèmes forestiers. Cette note de recherche propose une approche probabiliste pour estimer, à l'aide du lidar, le volume de bois sur pied lorsque l'inventaire forestier est effectué au moyen de placettes à aire fixe. La mesure de la hauteur du couvert supérieur (modèle numérique de la cime) avec le lidar est effectuée sur toute la zone d'étude. Les pixels de hauteurs qui en résultent sont utilisés comme information auxiliaire à coupler au volume de bois sur pied obtenu via les placettes sur le terrain. L'estimateur de rapport pour le volume total de la forêt est dérivé d'une approche d'échantillonnage entièrement probabiliste, de concert avec un estimateur non biaisé de sa variance d'échantillonnage et avec l'intervalle de confiance correspondant. La procédure proposée a été testée à Bosco della Fontana, une forêt de plaine dans le nord de l'Italie. Avec cette procédure, l'intervalle de confiance qui a été obtenu pour l'estimation du volume total, au niveau de probabilité de 0,95 , est plus petit et représente environ les $2 / 3$ de celui qui a été obtenu en utilisant uniquement les données des placettes sur le terrain.

[Traduit par la Rédaction]

\section{Introduction}

Information about the state and changes to forest stands is important for environmental and timber assessment on various levels of forest ecosystem planning and management (Köhl et al. 2006). Standing volume and aboveground tree biomass are key parameters in this respect. Over the last decades survey methods and techniques for assessing such dendrometrical attributes have greatly advanced (Corona and Marchetti 2007). Among others, airborne laser scanning (ALS) techniques have developed to the point that they can provide image-like vertical profiles of forest vegetation. The most widely used system is lidar (light detection and

Received 12 December 2007. Accepted 19 August 2008.

Published on the NRC Research Press Web site at cjfr.nrc.ca on 29 October 2008.

P. Corona. ${ }^{1}$ Dipartimento di Scienze dell'Ambiente Forestale e delle sue Risorse, Università della Tuscia, via San Camillo de Lellis, 01100 Viterbo, Italy.

L. Fattorini. Dipartimento di Metodi Quantitativi, Università di Siena, P.za S. Francesco 8, 53100 Siena, Italy.

${ }^{1}$ Corresponding author (e-mail: piermaria.corona@unitus.it). ranging), which transmits laser pulses and detects the backscattered signal (Köhl et al. 2006).

ALS technology is increasingly being applied in forest ecosystem surveys (e.g., see review papers by Lefsky et al. 2002; Lim et al. 2003; Hyyppä et al. 2004; Næsset et al. 2004; McRoberts and Tomppo 2007). Indeed, in recent years, ALS has been established as the standard method for the acquisition of high-precision topographic data of large areas. This fact has contributed to decreased operational costs, so that ALS data are distinctively developing into cost-efficient covariates to support forest inventory.

Although most ALS systems have been designed for purposes other than forest inventory, they have proven to be suitable for the measurement of dendrometrical attributes such as tree height and crown cover, among others (e.g., Magnussen and Boudewyn 1998; Hall et al. 2005; Koukoulas and Blackburn 2005; Heurich 2008). On the other hand, the exploitation of such measurements for the assessment of timber volume or growing stock and biomass frequently involves uncertainty that must be recognized when supporting forest management and planning.

The accuracy of lidar measurements is highly dependent on both the extrinsic specifications of the ALS survey (e.g., 